\title{
The creativity of waste management in Payakumbuh City, West Sumatera
}

\section{Kreativitas pengelolaan sampah di Kota Payakumbuh, Sumatera Barat}

\author{
Moh. Ilham A. Hamudy \& Mujaeni Mujaeni* \\ Badan Penelitian dan Pengembangan Kementerian Dalam Negeri \\ Address: Jalan Kramat Raya 132, Senen, Central Jakarta, Jakarta, Indonesia 10450 \\ E-mail: ilhamhamudy80@gmail.com \& muzaeni12@gmail.com*
}

Article History: Received 31 January 2020; Accepted 19 January 2021; Published Online 10 February 2021

\begin{abstract}
Payakumbuh City continues to struggle with its waste management problem despite winning several prestigious Adipura awards. The local government has issued various handling instruments; therefore, it takes practical efforts to deal with it. This study's objective was to find a solution to the waste problem in Payakumbuh City, West Sumatra. With descriptive methods and qualitative approach, the study found not a few unscrupulous citizens still littering and not complying with the provisions of the disposal time that has been set in Payakumbuh Regional Regulation Number 4 of 2014. Besides including increasing community involvement Payakumbuh City is making several improvements. On the other side, some innovation and creativity were needed to solve the problem. The innovations and creativity were in two aspects: law enforcement and its residents' involvement, by promoting waste sorting, deployment of biopores, establishing waste banks, plastic waste processing, and composting. The two aspects must be supported by the provision of cross-subsidies for recycled products from the waste banks; facilitation of organic waste management training to the waste bank management community; and the establishment of a regional waste and fertilizer company a synergy between cleanliness, renewable energy, and agriculture.
\end{abstract}

Keywords: waste; biopores; compost; waste bank; waste sorting

\begin{abstract}
Abstrak
Kota Payakumbuh terus berjuang mengatasi masalah pengelolaan sampahnya meski telah meraih beberapa penghargaan bergengsi Adipura. Berbagai instrumen penanganan telah dikeluarkan oleh pemerintah daerah, oleh karena itu, dibutuhkan upaya praktis untuk mengatasi masalah tersebut. Penelitian ini bertujuan untuk mencari solusi atas permasalahan sampah di Kota Payakumbuh, Sumatra Barat. Dengan metode deskriptif dan pendekatan kualitatif, studi ini menemukan tidak sedikit oknum warga yang masih membuang sampah sembarangan dan tidak mematuhi ketentuan waktu pembuangan yang telah diatur dalam Perda Nomor 4 Tahun 2014. Selain meningkatkan keterlibatan masyarakat Kota Payakumbuh membuat beberapa perbaikan. Di sisi lain, diperlukan inovasi dan kreativitas untuk menyelesaikan masalah tersebut. Inovasi dan kreativitas dalam dua aspek yaitu penegakan hukum dan pelibatan warga dengan mendorong pemilahan sampah, penerapan biopori, pembentukan bank sampah, pengolahan sampah plastik, dan pengomposan. Kedua aspek tersebut harus didukung dengan pemberian subsidi silang untuk produk daur ulang dari bank sampah; fasilitasi pelatihan pengelolaan sampah organik kepada masyarakat pengelola bank sampah; serta pembentukan perusahaan sampah dan pupuk daerah, untuk mewujudkan sinergi antara kebersihan, energi terbarukan, dan pertanian.
\end{abstract}

Kata kunci: sampah; biopori; kompos; bank sampah; pemilahan sampah

\section{Introduction}

Waste management in Indonesia is a complicated matter (Whiting 2019). In the study of Sustainable Waste Indonesia (SWI) in 2017, as much as $24 \%$ of waste in Indonesia was not appropriately managed. The approximately 65 million tons of waste produced every day in Indonesia, 15 million tons were not processed due to the inadequacy of the waste management system; $60 \%$ of the waste was organic waste, $14 \%$ was plastic waste, followed by paper waste $9 \%$, metal $4.3 \%$, glass, wood, and other materials $12.7 \%$ (CNN Indonesia 2018). The Ministry of Environment and Forestry recorded that, nationally, 175 thousand tons of waste were produced per day in 2019 (Baqiroh 2019). Assuming that each person produced 0.7 kilograms of waste per day, nationally, that figure is equivalent to 
64 million tons per year. Mostly it was located in metropolitan cities and large cities (Baqiroh 2019). It indicates that Indonesia's waste management is still not optimum and needs more attention (Indonesia-Investments 2019). Currently, the waste management system is focused on downstream handling, which is related to how to transport waste from its source to be placed in one disposal location, referred to as a landfill or Tempat Pembuangan Akhir (TPA). Policymakers should review the current waste management system since it is merely relocating the problem and not solving it permanently. The waste management system should focus more on the waste source while also improving waste collection management. The paradigm shift should be embraced by the government and the general public (Putra 2019).

One of the most important aspects of waste management is the sorting of waste from the waste source, and it correlates directly with the residents' behavior. The piling up of the waste would not happen if the residents did not throw it out indiscriminately. Sorting the waste starting at its source is the key to a successful waste management system (Sihombing 2018). The importance of waste sorting is shown in a study by Yudhistirani et al. (2015) in East Jakarta, which stated that waste sorting reduced waste by $33 \%$. The sorted waste made it easier for it to be recycled. Furthermore, the local government needs to manage organic waste, which comprises $67 \%$ of the total waste.

Referring to Law Number 18 of 2008 on Waste Management, every region must manage its waste. The regulation is an umbrella for regional regulations on waste management, and it defined waste management as a systematic, comprehensive, and sustainable activity that includes reducing and handling waste. Waste management can also be viewed based on the location of the source of the waste. For example, according to Indonesian National Standard (SNI 19-2454-2002), the operational management techniques in urban areas consist of storage up to the waste's final disposal, emphasizing the importance of sorting the waste from its source.

Presenting accurate waste management certainly needs strategic management (Table 1). This effort is to guide local governments to carry out their work to achieve the targets that have been set. In this way, it can produce decisive strategic steps to be implemented (Chaneta 2011). David (2011) coined a strategic management model in general, and the strategic management process consists of three stages: the formulation of strategies, implementation of strategies, and evaluation of strategies. Strategy formulation, also known as strategic planning, involves several aspects, such as vision and mission, internal and external audit of the environment, and long-term goals and objectives. While the strategy's implementation is to work on a predetermined plan, in the evaluation of the strategy, it aims to change or take corrective action against the strategy being implemented, either measuring success or the like.

Table 1.

Strategic aspects in waste management

\begin{tabular}{ll}
$\begin{array}{l}\text { Waste management } \\
\text { aspects }\end{array}$ & \multicolumn{1}{c}{ Explanation } \\
\hline $\begin{array}{l}\text { Strategy } \\
\text { formulation }\end{array}$ & $\begin{array}{l}\text { For example, they are arranged according to needs by making clear } \\
\text { regulations and reinforcing community involvement, such as waste } \\
\text { segregation and utilization. }\end{array}$ \\
$\begin{array}{l}\text { Strategy } \\
\text { implementation }\end{array}$ & $\begin{array}{l}\text { The key to the success of the plan that has been prepared, it can be done by } \\
\text { revising regulations and promoting community involvement through waste } \\
\text { management education to support the programs that have been launched. }\end{array}$ \\
Strategy evaluation & As a correction space to measure the success of the strategy, or so on. \\
\hline
\end{tabular}
Source: Processed from various sources (2019)

Meanwhile, appropriate waste management strategic management has always been an essential concern for local governments (Sharma et al. 2018). At the program formulation stage, stakeholders can carry various efforts, such as applying a clear and firm legal basis. The policy evidences this in Sweden, making local governments responsible for recycling or disposing of household waste properly (Andersson \& Stage 2018). This effort can be made by revising regulations that are considered less 
effective in handling problems. In addition, the role of the community is equally important. Because handling waste is the government's responsibility and citizens (Abrauw et al. 2011), this role can be involved through waste segregation and utilization. It can be done by providing training and understanding to the community to support the program and comply with the policies that have been prepared (National Solid Waste Management Strategy 2014). In the implementation strategy, the policy steps that have been formulated, reliable execution is the key to success for planning (Chaneta 2011). Its implementation must be following the conditions of the problem because effective implementation depends on the compatibility of practices that refer to actual conditions (Udawatta et al. 2018). The next stage is evaluating the efforts that have been carried out. As David (2011) said, this is important for correct strategy, whether measuring success

The researcher had not found recent data about the total volume of waste in West Sumatera; however, the West Sumatra environment office recorded that the area produced 2.392 tons of waste per day in 2017. Padang City contributed the most, as much as 494 tons per day, Bukittinggi City was in second place with 183 tons, followed by Pasaman District 162.25 tons, West Pasaman 162.18 tons, and Agam Regency 145.29 tons per day (Harlina 2017). In 2018, West Sumatera produced 1.072.884 tons of waste from its districts and cities, of which 628.920 tons were able to be managed; however, 443.964 tons were not (Syofiadi 2019). One of the cities in West Sumatra with fairly good waste management is Payakumbuh City. In early 2019, the city received its Adipura awards for the eleventh time from the central government. This award focuses on environmental aspects, one of which is the waste problem. The government uses Adipura as an instrument to achieve the national policy and strategy targets to reduce waste by $30 \%$ and managed waste by $70 \%$ by 2025 (Arumingtyas 2019). Adipura serves as the government's strategic tool in solving the waste problem in the regions.

Payakumbuh City produces 70 tons of waste every day, dominated by household and plastic waste (Hidayat 2019). Referring to Law Number 23 of 2014 on Regional Government, waste matters, mainly the development of the waste system and management, ideally is maintained by the government of the city or district. Each district or city must manage its waste and issue licenses for recycling or processing, transporting, and monitoring the waste should be conducted by the private sector. The city has issued Payakumbuh Regional Regulation Number 4 of 2014 concerning Waste Management. Payakumbuh City struggles with its waste management problem despite winning several prestigious Adipura awards, due to some irresponsible residents are still littering and causing piling up of waste in several locations (Ario 2019).

Ediana et al. (2018) showed that most Payakumbuh City residents still prefer to dispose of their waste behind their house directly, use a single container without sorting the wet and dry waste, and expect the village waste collection officers to collect the piled-up waste. This behavior violates Regulation Number 4 of 2014 on Waste Management, particularly Article 18, which states that the public is prohibited from disposing of waste in the open, and Article 27 emphasizes that the waste collection is responsible for the village, hamlet, and neighborhood. The study concluded that reduce, reuse, and recycle (3r) waste management was not optimally. It seems that the relationship between the residents' behavior and waste management, $3 \mathrm{r}$ were significantly related. The community's failure to sort their waste did not support the implementation of $3 \mathrm{r}$ waste management. The respondents' knowledge and employment status did not have a significant relationship with $3 \mathrm{r}$ waste management.

On the other hand, the landfill in Payakumbuh City also holds the waste from Bukittinggi City and Lima Puluh Kota District, regulated through Governor Regulation Number 193 of 2014. Although each region handles waste distribution, Payakumbuh City's government must allocate a particular budget in waste management, especially for landfill management (Liesmana 2019). This study reviewed Payakumbuh City's waste management; it has a significant role in waste management, reducing waste, and processing. Realizing this role, Payakumbuh City implemented various policies to improve its waste management, which is based on Payakumbuh City Regional Regulation Number 4 of 2014. The waste management referred to in this study is the Payakumbuh City Government's effort in managing waste, both in the processing of the waste and its reduction. Waste management 
is also widely practiced in other regions. Surabaya City converts its waste into electricity by building a Waste-to-Energy Plant or Pembangkit Listrik Tenaga Sampah (PLTSa) in Benowo Districts. Surabaya City also built community-based waste management by building waste banks at several points and educating the public to manage their waste (Jayani 2019). West Java has also already had a waste management cooperation using a Public-Private Partnership (PPP) scheme or locally called Government Cooperation with Business Entities or Kerjasama Pemerintah dan Badan Usaha $(K P B U)$ in the landfill of Nambo (Ferza et al. 2019).

Studies on waste management have been widely publicized; for example, Liesmana (2019) examines the best practice of waste management policy in urban areas, such as Padang and Payakumbuh City. Liesmana (2019) found that Padang and Payakumbuh City have different budget sources for their waste management. Payakumbuh City, which collaborates with Bukittinggi City and Lima Puluh Kota District, budgeted its waste management through the West Sumatra Province Regional Budget or Anggaran Pendapatan dan Belanja Daerah (APBD). Nevertheless, the waste management of Padang and Payakumbuh City is not practical, in the two study locations, there were still many obstacles. There is also a study exploring the scenario of developing a waste management system in West Pasaman District. The study conducted by Aziz et al. (2019) uses a scale approach to processing waste at the regional and city level. The study found that existing waste management was only able to manage $9.13 \%$ of the total waste. As a result, the waste piles up due to inadequate facilities and infrastructures. In another study, Lestari \& Azkha (2010) examined waste management behavior in food vendors and tourists in Padang Beach and found that their behavior still needed improvement. The local government advised increasing the education related to waste management in the Padang Beach area and provide sanctions for those who violated the regulation.

Other studies conducted outside of West Sumatera, such as Setiadi (2015), studied community-based waste management in Yogyakarta's urban settlement areas. This study used a participatory approach, and the study found that the community could identify, analyze, map the problems, potentials, threats, obstacles and find solutions for their waste problem. The communities solve their problems through community-driven activities. A study related to community participation in waste management was carried out by Sulistiyorini et al. (2015); the study, the community involvement in waste management was conducted by having a community work activity (kerja bakti). The community is also involved at the neighborhood level, although it was still not optimum. In a study by Widyarsana \& Zafira (2015) on the development of a waste management system in Tangerang District, it found that most of the community $(60 \%)$ do not have a garbage container, and the waste collection system is mostly inexistent due to the limited number of temporary disposal sites. Waste management relies solely on the waste collection system; the landfill also uses the open dumping method with minimal facilities.

Based on some of the studies, this study considers it essential to show Payakumbuh City's efforts in managing waste. As a city that has won several Adipura awards, the public needs to know its waste management system. Although several studies discussed Payakumbuh City's management, these did not review the overall management efforts, both processing and reducing waste, and the challenges in waste management. Therefore, this study carries out to complement these deficiencies. For this reason, this study discussed waste management in Payakumbuh City in two aspects, the regulatory side, including law enforcement, and community involvement.

\section{Research Method}

This study combined descriptive methods and document analysis. The descriptive method was intended to describe the overall waste management efforts, the processing and the reduction, and the waste management system (Sugiyono 2014). The literature study method was intended to collect information relevant to regulations, including enforcement and legal actions, and the community involvement in managing waste. This information was obtained through reviewing books, scientific works, thesis, dissertations, encyclopedias, and the internet (Zed 2004).

This field study was carried out between March and August 2019; however, the data is updated until February 2020. This study used the interview as the data collection method by gathering information 
from the Payakumbuh City environment office, the spatial planning and sanitation office, municipal police (Satuan Polisi Pamong Praja), managers of waste banks, plastic waste processing units, markets, several village heads and their staff, the regional landfill, scavengers, and the general public. The approach used in this study was a qualitative approach, which was an appropriate approach to use since waste management was considered to be multidimensional (Alwasilah 2003). The collection of facts and data was conducted by reviewing Payakumbuh City's waste management in the mainstream mass media to enrich the analysis.

\section{Results and Discussion}

\section{Law enforcement}

To manage the waste problem, the Payakumbuh City government reviewed the implementation of Regional Regulation Number 4 of 2014 on Waste Management. Payakumbuh City did not have a specific regulation on plastic waste management. The existing regulation was a regulation on the general waste that was not implemented optimally and had no deterrent effect. The socialization of the regulation has been carried out; however it was not implemented properly.

In 2018, the Payakumbuh City environment office, together with the municipal police, had proposed the revision to the Regional House of Representative or Dewan Perwakilan Rakyat Daerah (DPRD). The proposed regulation was under discussion and review by the Regional House of Representatives and contained sanctions to the public and institutions that violate the regulation. Several revisions were made in the proposed regulation to make it more effective in enforcing and taking action against the violators. Specific sanctions and penalties were more clearly defined in detail compared to the previous regulation. Aside from the minor criminal acts (tipiring) charges, the revised regulation will define administrative sanctions, such as revocation of business entity licenses that violate regulations, fines for those who dispose of their waste outside the schedule, and others. With this revision, officers can collect fines directly on the spot.

For the minor criminal charges, the city government reduced the imprisonment from six months to three months to cut down the regional regulation's lengthy court process. A six-months imprisonment sanction means the case has to go through formal legal rules where it must go through the prosecutor's office's investigation process and a trial in court, and it was time-consuming. With a three months imprisonment, the municipal police could immediately take legal action against the perpetrators. The law enforcement in Payakumbuh City was in line with the study by Candrakirana (2015), which stated that law enforcement in waste management was also an embodiment of the government in applying sound environmental governance principles to raise awareness the community of a good and healthy environment.

Since mid-2018, the Payakumbuh City environment office, together with the municipal police, has been intensively conducting enforcement operations and socializing the sanction and penalty to the residents for the Regional Regulation violations on Waste Management. Officers of the environment office and municipal police were stationed at several points where violations were suspected. As a result of these activities, the number of violations has begun to decrease; however, many people still violate the regulation. The city government proposed a revision on the Regional Regulation on Waste Management to increase its effectiveness. For a deterrent effect, based on Payakumbuh City Regional Regulation Number 4 of 2014 on Waste Management and Mayor Circular Letter Number 660.931/ WK-PYK/2018 on Enforcement of this Regional Regulation, starting in 2018, the city government enforced the penalty on residents who violated the regulation. The perpetrators were charged with minor crimes, which carried a maximum penalty of 50 million IDR, or three months imprisonment. Municipal police collaborated with the environment office to monitor and enforce the regulation (Puspita et al. 2019).

A sign posted at the Payakumbuh City temporary laystall informs the disposal schedule residents (6:00 pm to 6:00 am); however, many residents were not following the schedule. Various appeals and socialization have also been carried out regarding this matter. Community awareness in applying the 
Clean and Healthy Life Behavior or Perilaku Hidup Bersih dan Sehat (PHBS) in their households was still low. Therefore, strict enforcement was carried out by the municipal police as a regional enforcement unit and a form of support to the environment office in controlling waste disposal.

The head of municipal police Payakumbuh City confirmed that the joint team conducted enforcement operations on residents who violated the regulation. Three municipal police teams were tasked with these operations. The municipal police and the environmental task force also provided socialization and education to residents to dispose of their waste during the operation correctly. In the early stages, the municipal police conducted non-judicial actions to inform and reprimand the perpetrators. After that, should they violate the regulation, they would be charged with minor criminal charges. There were at least eleven points monitored by the team, divided into three joint teams every day. Some of these points were Ibuh Market, Dika Farma Pharmacy, in front of the municipal waterworks or Perusahaan Daerah Air Minum (PDAM) and Latsitarda Street, and the border between Tanah Mati and Parit Rantang Village.

Table 2.

Waste management in aspects of law enforcement

\begin{tabular}{ll}
\hline $\begin{array}{c}\text { Waste management } \\
\text { aspects }\end{array}$ & \multicolumn{1}{c}{ Explanation } \\
\hline Strategy formulation & $\begin{array}{l}\text { Payakumbuh reforms regulations that highlight the problem of waste. It is } \\
\text { based on the absence of a deterrent effect arising from the regulation for } \\
\text { violators. }\end{array}$ \\
$\begin{array}{l}\text { Strategy } \\
\text { implementation }\end{array}$ & $\begin{array}{l}\text { Revise Payakumbuh Regional Regulation Number } 4 \text { of } 2014 \text { to provide a } \\
\text { deterrent effect to the stubborn community to grow a good waste ecosystem. } \\
\text { Carry out raids and outreach to the public to understand the policy. } \\
\text { The act of revising is an attempt to review the policies that have been } \\
\text { previously carried out. It then resulted in several efforts made by } \\
\text { Payakumbuh City. }\end{array}$ \\
\hline
\end{tabular}

Source: Processed from various sources (2019)

The officers were deployed in other locations in stages, in coordination with the youth organization, neighborhood, hamlet, village, and sub-district, by forming a waste task force at each location. Violations include waste disposal in locations not designated as waste disposal sites or disposal in locations designated as waste disposal sites but did not comply with the disposal schedule (Falepi 2014). The target was not to apprehend the people who disposed of their waste irresponsibly; instead, they make them feel responsible for Payakumbuh City's cleanliness. Later on, municipal police might also charge the perpetrator with minor criminal charges. Legal actions implemented in Payakumbuh City showed that the community's understanding and awareness significantly reduce waste problems (Suprapto 2005). Domestic waste management starts with awareness and is followed by the willingness and concrete actions (Sudarwanto 2010); however, this awareness was lacking in Payakumbuh City. An instrument was needed to force people to realize the importance of proper waste management.

Presumably, the sub-optimum awareness in Payakumbuh City was due to a lack of knowledge about the environment. It takes a long time to form community behavior, and the behavior survives when it is based on knowledge. In this case, the knowledge is about waste, its impact, and how to manage it. Knowledge will direct the mindset, perception, or attitude of a person; they will do the right thing because they know the consequences of their actions. Hermawan \& Roesman (2008) stated that knowledge about environmental cleanliness influences people's waste management behavior. Riswan et al. (2011) stated that some factors that had positive correlations with household waste management were education level, family income, knowledge, and willingness to pay regional fees.

Another factor that influences behavior is attitude. A right attitude or perception about something will encourage a person to do a specific behavior. One of the researchers who found a positive correlation between attitudes and behavior was Sudiharti \& Solikhah (2012); however, that finding differs from 
those found in a study by Mulasari (2012), which stated no relationship between people's attitudes and behavior in managing waste. Kumurur (2008) also stated that attitude was not related to concern for environmental quality. As described earlier, in strategic management, Payakumbuh City has done three aspects: the formulation of the strategy, implementation of strategies, and evaluation of strategies (Table 2).

\section{Community involvement and waste sorting}

Waste management is the government's and the residents' responsibility (Abrauw et al. 2011). The community needs to understand that they are essential in finding waste management solutions because the community is the waste producer. The moral responsibility for cleanliness rests on the shoulders of every resident. The community must be involved in handling waste, and every village in Payakumbuh City has an organization responsible for waste management. Payakumbuh City government prepares the infrastructures, tools, and other facilities. According to the head of the spatial and sanitation office, the volume of waste brought to the landfill can be reduced by more than $60 \%$ through the community-based waste management program. In the villages that have not been served by the spatial planning and sanitation office, residents' waste is handled by dumping it in a pit. The community-based waste management program's implementation began with building infrastructure and the village facilities, such as integrated waste treatment facilities, motorized pedicabs, and garbage chopper. The waste management system starts at the household level, with the separation between organic and non-organic waste.

At present, only a handful of families carry out waste sorting before disposal. Payakumbuh community awareness on waste management has not yet been formed. It will be much easier to manage the waste when the waste is sorted at the household level (Katadata 2019). Responding to the condition, the department of spatial planning and sanitation has continued to take several steps, one of which was through cooperation with the family welfare development unit to form a waste bank. Family Welfare Development has a group of assisted housewives or what is called Dasa Wisma. Each Dasa Wisma will have one group whose management will manage the waste bank. Each village was also equipped with a motorized waste transport pedicab with a speaker installed. Its purpose was to help socializing waste management to the surrounding residents. The pedicab drove around the neighborhood, transported the waste, and conducted socialization of waste management. The funding to procure the pedicab came from two sources, the Environment Office budget and the village budget. Despite the two funding sources, all transported waste was placed in two transit depots; however, some were directly transported by trucks to be disposed of at the landfill. Waste sorting carried out in the villages is designated as waste management pilot projects. In these villages, the city environment office routinely assists, including in the waste sorting process.

Thus, in general, the benefits of independent, community-based waste management are that it fosters public awareness to manage waste properly; build their habits in reducing, sorting, and recycling of waste; opening business opportunities; no fees for waste collection, and it even provides income for the village or other organizations. The most important benefit is that independent waste management can reduce water, soil, air pollution, and dangerous disease sources (Marwati 2013).

\section{Biopores deployment}

Biopores are pores in burrows (small tunnels) formed by the soil microorganism's activity or plant roots. Biopores infiltration hole is a cylindrical hole dug vertically into the soil with a diameter of $10-30 \mathrm{~cm}$, a depth of $100 \mathrm{~cm}$, and not exceeding the groundwater level's depth. The hole is filled with organic waste to encourage the formation of biopores. Biopores infiltration hole is an environmentally friendly and appropriate technology to overcome floods and waste problem by 1) increasing water absorption, 2) turning organic waste into compost, 3) utilizing the role of soil microorganism and plant roots, 4) overcoming problems caused by standing water, such as dengue fever and malaria, and 5) as 'carbon sink' to help prevent global warming (Maryati et al. 2010).

Every household in Payakumbuh City with a large yard was invited to participate and provided with two pits, one for organic and one for non-organic waste, and when the waste collection staff pick up 
the waste, it was sorted. For organic waste, the city government provides a composter; however, due to limited funding, currently, there are only 250 composters for the seven pilot project villages. The composters were also donated to several schools, and the objective was that they would be used as a learning tool for the students in making compost. The composters program was then refocused on the villages as waste processing pilot projects.

Biopores were made for houses that did not have large yards. The organic waste was put into the biopores holes, and, after some time, it would be used as fertilizer. A disposal bin was also provided for non-organic waste such as plastic and cans. An organic fertilizer processing and ornamental plant program were initiated on the waste collection site's sub-district level. With organic waste processing, fertilizer can automatically be produced, and it can be used as fertilizer for the ornamental plant seedling to be planted around the city (Hilwatullisan 2014).

\section{Establishment of waste banks}

A waste bank is a recycling program. The waste bank is one of the strategies to implement $3 r$ (reuse, reduce, recycle) in waste management, with an economic incentive conducted at its source, at the community level. Participating in a waste bank program means having a recycling behavior (Selomo et al. 2016). Payakumbuh City began to promote waste banks nine years ago. At that time, it was Mayor Josrizal Zain who popularized the waste bank in Payakumbuh City. To date, there are eleven waste banks spread across Payakumbuh City, and all of them are in schools (elementary to senior high school). The waste that burdened the city government was transformed into a source of income for the residents. Waste was sorted into four containers: organic waste, paper, inorganic plastic or bottles, and hazardous and toxic waste. Plastic waste, for example, was sold directly. The wet waste was processed into compost. The waste bank collection posts were provided in every village, school, and market. By looking at examples in Thailand, the Pakayumbuh City environment office involved various schools in overcoming this problem by educating them on waste management. Various policies were implemented, one of which was through a recycled plastic creation competition (Singseewo 2017).

During the national waste awareness day, the Pakayumbuh City environment office created a onekilogram plastic waste program, where a kilogram of waste can be exchanged for one plant seedling and one cleaning tool. The results were quite satisfying; almost all schools welcomed the program by sending much waste, some had 20 kilograms, and some even had 30 kilograms of waste. There were only approximately 200 seedlings available. Some schools have a memorandum of understanding $(\mathrm{MoU})$ with the Payakumbuh City environment office in waste management. One of them was National Vocational High School 2 of Pakayumbuh City, which processed plastic waste and sold it to distributors with varying prices according to its quality.

Plastic waste banks were still dominated by schools (Dwipasari 2014). In 2016, all villages in Pakayumbuh City already had a waste bank; however, due to the limited human resources and budget, the waste bank could not fully operate. The environment office promised that, in 2019, it would reactivate the waste bank. The waste bank's activation started from the Integrated Waste Disposal Site or Tempat Pengolahan Sampah Terpadu (TPST). The development of this waste bank was intensified, from the waste collection process to its distribution.

As the latest information, the new Payakumbuh City Government will enact local regulations to regulate the use and processing of plastic waste in its area. Payakumbuh City regional secretary stated that local regulations related to plastic waste management were quite significant, considering that plastic waste is difficult to decompose. According to the secretary, the amount of waste produced in Payakumbuh City reached 200 tons per day. An appropriate program was needed to minimize the waste to overcome the problem. For this reason, Payakumbuh City encouraged the implementation of waste management from the villages, with a plastic waste sorting system before disposing it at a final disposal site. The waste sorting system was carried out because the plastic waste does not decompose, and sorting it keeps the pile of waste at the final disposal in check (Saputra 2019). 


\section{Plastic waste processing}

The head of the Payakumbuh City environment office stated that non-organic waste, especially plastic, was processed only on a small scale. The production of plastic waste in Payakumbuh City was approximately 14.3 tons per day. The city government targeted that $30 \%$ of it can be managed this year. The downstream management of plastic waste is expected to increase this high-valued waste's economic value, all junior and senior high schools in Payakumbuh City have carried out plastic waste processing. One of the relatively well-functioning waste banks was the waste bank in National Vocational High School 2 of Pakayumbuh City. The school had an MoU with all middle and high schools or vocational high schools on plastic waste. Plastic waste was collected from other schools for recycling, and National Vocational High School 2 of Pakayumbuh City processed them. The result, in the form of plastic pellets, was sold to Pekanbaru City. The next target was to process plastic waste into finished materials such as plastic cups.

National Vocational High School 2 of Pakayumbuh City also cooperates with other parties outside the school, such as the Sapaku Village, Sawahpadang Aua Kuniang Districts. The cooperation was aimed at the utilization of the school plastic chopper machines (Mindarta et al. 2018), designing of machines that will be made by the National Vocational High School for the bamboo craftsmen, and also providing applicable technology for processing plastic waste into finished goods and bamboo artworks in Sapaku Village. Besides the schools, there were waste banks managed directly by the community, such as the Peduli Waste Bank; however, that waste bank was not successful, it did not function as expected. Its location, which was quite far from the highway in Subarang Betung Subdistrict, West Payakumbuh District, caused the Peduli Waste Bank to be deserted by its customers. The waste bank, which was established in 2013, was on the side of the road so that customers could access the locations quickly. In 2017, the Peduli Waste Bank received assistance from the Pakayumbuh City environment office in the form of a building; however, because the land did not belong to them, the building did not have an appropriate building permit, the waste bank was relocated to another location.

At the time of the study, only 50 customers joined the Peduli Waste Bank, whereas previously in its initial location, they had a hundred customers. The distance was the main reason that the customers were reluctant to deposit their waste there, despite the residents' enthusiasm. Many of them hoped that the waste bank would have a pickup service to facilitate waste transportation (Tahar 2018); however, that hope was cut short over an inadequate budget to cover transportation costs. Meanwhile, motorized waste transport pedicabs do not pass through the location of the waste bank. The vehicle only operates on large roads. As a result, many residents dispose of their household waste around their house.

\section{Composting}

Traditional markets are usually synonymous with muddy places and garbage scattered everywhere; however, this was not the Ibuh Market case in Payakumbuh City. Traders in this market understand how to manage their waste. In 2007, the Payakumbuh City environment office built an integrated waste disposal site to process market waste (Mangkara et al. 2018). The city government wanted to change their behavior and provide an example to the community that their waste can be turned into compost, not necessarily needing to be thrown away. There were approximately three tons of waste produced by Ibuh Market per day. All organic waste was then taken to an integrated waste disposal site and processed into compost. This method was very effective in reducing waste brought to the landfill.

Ibuh Market produces 450 kilograms of compost per month. Since 2007, Ibuh Market has had an organic fertilizer processing plant just behind its east side. Payakumbuh City government and private parties built it through corporate social responsibility. Ibuh Market organic fertilizer production has reached 450 kilograms per month at the maximum and is sold to the women farmers group in the Payakumbuh City for 500 IDR per kilogram or 5.000 IDR per sack. The process of sorting organic and non-organic waste at the Ibuh Market proved easy and, with 
the availability of the waste treatment facility, the 2.000 traders started to do their sorting. Ibuh Market waste production reached three tons per day, 700 kilograms per day were organics, processed at the waste disposal site by eleven workers, including the operator. The proceeds from organic fertilizer sales were not enough to be added to the regional treasury budget; however, it could fund this operation independently and pay its workers. Organic waste treatment in Ibuh Marketled Payakumbuh City to achieve healthy city's title for five consecutive years. Payakumbuh City maintained the highest award, namely Wistara Swasti Saba given by the Ministry of Health. It is not a surprise that Ibuh Market always looks clean and neat. The community is increasingly aware of the importance of managing waste properly for their convenience; however, all that did not happen quickly. The city government faced difficulties when implementing this rule (Sukresno et al. 2019). The city government tirelessly approached the community, and finally, the community and traders in the market realized that the cleanliness had a tremendous impact on them.

Table 3.

Waste management in the aspect of community involvement

\begin{tabular}{ll}
$\begin{array}{l}\text { Waste management } \\
\text { aspects }\end{array}$ & \multicolumn{1}{c}{ Explanation } \\
$\begin{array}{l}\text { Strategy } \\
\text { formulation }\end{array}$ & $\begin{array}{l}\text { Payakumbuh boosts waste management through increasing community } \\
\text { involvement. This is based on the position of the community, which is an } \\
\text { important element in building changes in waste management. }\end{array}$ \\
& $\begin{array}{l}\text { This involvement is done by facilitating solid waste facilities and infrastructure } \\
\text { so that the community is easily involved, namely through community-based } \\
\text { waste management programs. Education on the importance of sorting }\end{array}$ \\
wtrategy & $\begin{array}{l}\text { waste is also provided. Utilization of waste is encouraged by making } \\
\text { implementation }\end{array}$ \\
& $\begin{array}{l}\text { biopores, establishing bank waste, processing plastic waste, and making } \\
\text { Various efforts that have been made are a response from the work process, }\end{array}$ \\
Strategy & which still lacks the impact of improvement, especially the role of the \\
evaluation & community in making improvements.
\end{tabular}

Source: Processed from various sources (2019)

Ibuh Market established a radio station in the Radio Land Market to maintain a clean and healthy life behavior in the market. This radio broadcasts explicitly various information about cleanliness in the market. Radio Land has been around since 2008, and its function is to broadcast information to traders and visitors related to cleanliness, market management, and government programs. Also, an inspection by the food and drug supervisory agency conducts every three months. With a variety of sanitation programs, Ibuh Market has also become a pilot market in Payakumbuh City. Various efforts in community engagement cannot be released with waste management by Payakumbuh City. If summarized in the strategic management stages, such as strategy formulation, strategy implementation, and strategy evaluation (Table 3).

\section{Conclusion}

Although it has repeatedly received various awards from various parties in managing the city, Payakumbuh City is still plagued by waste problems that make the government struggle to solve them. For a city government far from the provincial government and supported by a limited budget, the Payakumbuh City government must be creative and innovative in overcoming waste. Various efforts that have been made, as described above, can be implemented to reduce the volume of waste and in regulating the way to manage the waste in Payakumbuh City. The city government has enforced Law Number 23 of 2014 on Regional Government, Law Number 18 of 2008 on Waste Management, and Government Regulations Number 81 of 2012 on Management of Household Waste and Other Waste Similar to Household Waste, which suggests that waste management must be community-based with an economic orientation. 
Payakumbuh City Government also must perform several efforts to ensure the sustainability of its actions. First, providing cross-subsidies for waste banks' recycled products. This subsidy will increase the marketing opportunities for recycled products and increase the waste banks' passion and creativity. The waste banks must be economically oriented and receive assistance on the recycled products' management, technology, and marketing. The banks should also be equipped with an organic waste treatment plant that produces fertilizer, biogas, and non-incineration electricity. Second, the facilitation of organic waste management training to the waste bank management community is needed. This initiative can be strengthened by incentives to tipping fees to the waste banks to reduce the waste and direct and facilitate the formation of waste bank cooperatives to ensure the sustainable marketing of the recycled products. Third, the formation of regional waste and fertilizer companies, so that there will be cross-subsidies between cleanliness, renewable energy, and agriculture. The company also expected to function in a synergy between work units, such as the environment office and the public works office.

\section{Acknowledgment}

The authors would like to thank the R\&D Center of the Regional Financial and Development of the Research and Development Agency of the Ministry of Home Affairs of the Republic of Indonesia and its staff to our sources. Moreover, especially our friend Darmawan Iswary who helps us in data collection in Payakumbuh City.

\section{References}

Abrauw A, Yunus HS, \& Giyarsih SR (2011) Perilaku masyarakat dalam pengelolaan sampah anorganik di Kecamatan Abepura Kota Jayapura. Majalah Geografi Indonesia 25 (1):1-14.

Alwasilah AC (2003) Pokoknya Kualitatif: Dasar-Dasar Merancang dan Melakukan Penelitian Kualitatif. Jakarta: Pustaka Jaya.

Andersson C \& Stage J (2018) Direct and indirect effects of waste management policies on household waste behaviour: The case of Sweden. Waste Management 76 (2018):19-27. https://doi.org/1 0.1016/j.wasman.2018.03.038.

Ario S (2019) Kota Payakumbuh raih penghargaan Adipura dan Nirwasita Tantra. Antara News Sumbar, 18 January. [Accessed 8 January 2020]. https://sumbar.antaranews.com/berita/240 351/kota-payakumbuh-raih-penghargaan-adipura-dan-nirwasita-tantra.

Arumingtyas L (2019) Adipura jadi instrumen capai target kelola sampah, mana kota terbersih dan terkotor? Mongabay, 15 January. [Accessed 8 January 2020]. https://www.mongabay.co.id/ 2019/01/15/adipura-jadi-instrumen-capai-target-kelola-sampah-mana-kota-terbersih-danterkotor/.

Aziz R, Ihsan T, \& Permadani AS (2019) Skenario pengembangan sistem pengelolaan sampah Kabupaten Pasaman Barat dengan pendekatan skala pengolahan sampah di tingkat kawasan dan kota. Jurnal Serambi Engineering 4 (1):444-450. https://doi.org/10.32672/jse.v4i1.977.

Baqiroh NFAB (2019) Timbulan sampah nasional capai 64 juta ton per tahun. Bisnis.com, 21 February. [Accessed 5 January 2020]. https://ekonomi.bisnis.com/read/20190221/99/891611/ timbulan-sampah-nasional-capai-64-juta-ton-per-tahun.

Candrakirana R (2015) Penegakan hukum lingkungan dalam bidang pengelolaan sampah sebagai perwujudan prinsip good environmental governance di Kota Surakarta. Yustisia 4 (3):581601. https://doi.org/10.20961/yustisia.v4i3.8690.

Chaneta I (2011) Strategic management process. Journal of Comprehensive Research 5 (2011):17-25.

CNN Indonesia (2018) Riset: 24 persen sampah di Indonesia masih tak terkelola. [Accessed 8 January 2020]. https://www.cnnindonesia.com/gaya-hidup/20180425101643-282-293362/ri set-24-persen-sampah-di-indonesia-masih-tak-terkelola.

David FR (2011) Strategic Management: Concepts and Cases. USA: Pearson Education. 
Dwipasari L (2014) Waste management model-based design character in junior high school as a tool of the economic empowerment. IOSR Journal of Business and Management 16 (10):38-48.

Ediana D, Fatma F, \& Yuniliza Y (2018) Analisis pengolahan sampah reduce, reuse, recycle (3r) pada masyarakat di Kota Payakumbuh. Endurance 3 (2):238-246.

Falepi R (2014) Payakumbuh Regional waste management. In: Towards Resilience and Smart Cities Conference, Jakarta. 1-44.

Ferza R, Hamudy MIA, \& Rifki MS (2019) Regional waste management cooperation in West Java. Bisnis \& Birokrasi: Jurnal Ilmu Administrasi dan Organisasi 26 (2):87-95. https://doi.org/ 10.20476/jbb.v26i2.10019.

Harlina N (2017) Volume sampah di Sumbar 2.392 ton per hari. Antara News Sumbar, 19 September. [Accessed 8 January 2020]. https://sumbar.antaranews.com/berita/212579/volume-sampahdi-sumbar-2392-ton-per-hari.

Hermawan Y \& Roesman HO (2008) Perilaku pedagang sayur dalam mengelola kebersihan lingkungan hidup. Jurnal Bumi Lestari 8 (2):186-192.

Hidayat T (2019) Produksi sampah Payakumbuh 70 ton perhari, sampah rumah tangga dan plastik mendominasi. KlikPositif.com, 30 November. [Accessed 8 January 2020]. https://news.klik positif.com/baca/61411/produksi-sampah-payakumbuh-70-ton-perhari--sampah-rumahtangga-dan-plastik-mendominasi.

Hilwatullisan H (2014) Lubang Resapan Biopori (LRB) pengertian dan cara Membuatnya di lingkungan kita. Media Teknik 8 (2):1-11.

Indonesia-Investments (2019) Environmental pollution: Indonesia's battle against plastic waste. [Accessed 8 January 2020]. https://www.indonesia-investments.com/news/todays-headlines/ environmental-pollution-indonesia-s-battle-against-plastic-waste/item9110.

Jayani DH (2019) Menengok pengelolaan sampah di Jakarta dan Surabaya. Katadata.co.id, 3 August. [Accessed 8 January 2020]. https://katadata.co.id/berita/2019/08/03/menengok-pengelolaansampah-di-jakarta-dan-surabaya.

Katadata (2019) Ragam kisah sukses sistem pengolahan sampah di berbagai negara. [Accessed 8 January 2020]. https://katadata.co.id/timpublikasikatadata/berita/5e9a4c4b5ea1f/ragam-kis ah-sukses-sistem-pengolahan-sampah-di-berbagai-negara.

Kumurur VA (2008) Pengetahuan, sikap dan kepedulian mahasiswa pascasarjana ilmu lingkungan terhadap lingkungan hidup Kota Jakarta. Ekoton 8 (2):1-24.

Lestari Y \& Azkha N (2010) Perilaku pengelolaan sampah pada penjual makanan dan pengunjung wisata di Pantai Padang. Jurnal Kesehatan Masyarakat Andalas 4 (2):97-102.

Liesmana R (2019) Best practice implementasi model kebijakan pengelolaan sampah perkotaan. Jurnal Administrasi dan Kebijakan Publik 3 (1):59-79. https://doi.org/10.25077/jakp.3.1.5979.2017.

Mangkara SB, Hasibuan HS, \& Chairani E (2018) Using life cycle inventory to improve the sustainability of traditional market management: A case study in Pandansari Market Balikpapan and Ibuh Market Payakumbuh. In: International Conference Series on Life Cycle Assessment: Life Cycle Assessment as A Metric to Achieve Sustainable Development Goals, 24-25 October, Jakarta.

Marwati S (2013) Pengelolaan sampah mandiri berbasis masyarakat. Service Report [online]. [Accessed 6 January 2020]. Yogyakarta: Universitas Negeri Yogyakarta. http://staff.uny. ac.id/sites/default/files/pengabdian/siti-marwati-msi/c9.pdf.

Maryati S, Ekosari E, \& Widodo E (2010) Teknologi tepat guna untuk mengatasi banjir dan sampah serta menjaga kelestarian air bawah tanah. Service Report [online]. [Accessed 6 January 2020]. Yogyakarta: Universitas Negeri Yogyakarta. https://staffnew.uny.ac.id/ upload/131832411/pengabdian/Lubang+Resapan+BIOPORI.pdf.

Mindarta EK, Wibowo AA, \& Putra ABNR (2018) Designing portable chopping plastic waste machine utilizing electric motor. In: International Mechanical and Industrial Engineering Conference, 30-31 August, Malang. 
Mulasari SA (2012) Hubungan tingkat pengetahuan dan sikap terhadap perilaku masyarakat dalam mengolah sampah di Dusun Padukuhan Desa Sidokarto Kecamatan Godean Kabupaten Sleman Yogyakarta. Kes Mas: Jurnal Fakultas Kesehatan Masyarakat 6 (3):204-211. https:// doi.org/10.12928/kesmas.v6i3.1055.

National Solid Waste Management Strategy (2014) Federated States of Micronesia National Solid Waste Management Strategy 2010-2014. Samoa: Secretariat of the Pacific Regional Environment Programme (SPREP).

Puspita L, Kurnia ML, \& Yevendri Y (2019) Law enforcement model in community based waste monitoring and management as a realization of good environmental governance principles in West Sumatera, Indonesia. Unifikasi: Jurnal Ilmu Hukum 6 (1):1-6.

Putra PH (2019) Mengubah paradigma pengelolaan sampah Ibu Kota. Tempo.co, 26 July. [Accessed 8 January 2020]. https://kolom.tempo.co/read/1228686/mengubah-paradigma-pengelolaansampah-ibu-kota.

Riswan R, Sunoko HR, \& Hadiyarto A (2011) Pengelolaan sampah rumah tangga di Kecamatan Daha Selatan. Ilmu Lingkungan 9 (1):31-39. https://doi.org/10.14710/jil.9.1.31-38.

Saputra E (2019) Pemko Payakumbuh akan buat perda pengolahan sampah Plastik. Antara News Sumbar, 27 November. [Accessed 8 January 2020]. https://sumbar.antaranews.com/berita/ 309260/pemko-payakumbuh-akan-buat-perda-pengolahan-sampah-plastik.

Selomo M, Birawida AB, Mallongi A, \& Muammar M (2016) Bank sampah sebagai salah satu solusi penanganan sampah di Kota Makassar. Media Kesehatan Masyarakat Indonesia 12 (4):232240.

Setiadi A (2015) Studi pengelolaan sampah berbasis komunitas pada kawasan pemukiman perkotaan di Yogyakarta. Jurnal Wilayah dan Lingkungan 3 (1):27-38.

Sharma A, Ganguly R, \& Gupta A (2018) Matrix method for evaluation of existing solid waste management system in Himachal Pradesh, India. Journal of Material Cycles and Waste Management 20 (3):1813-1831. https://doi.org/10.1007/s10163-018-0703-z.

Sihombing RC (2018) Pemilahan, kunci sukses pengelolaan sampah. Media Indonesia, 3 March. [Accessed 8 January 2020]. https://mediaindonesia.com/read/detail/147689-pemilahankunci-sukses-pengelolaan-sampah.

Singseewo A (2017) Promotion of a waste recycling bank in schools: A case study in a municipality school in Thailand. New Trends and Issues Proceedings on Humanities and Social Sciences 4 (1):329-334. https://doi.org/10.18844/prosoc.v4i1.2273.

Sudarwanto S (2010) Peran strategis perempuan dalam pengelolaan limbah padat bernilai ekonomi. Ekosains 2 (1):65-74.

Sudiharti S \& Solikhah S (2012) Hubungan pengetahuan dan sikap dengan prilaku perawat dalam pembuangan sampah medis di Rumah Sakit PKU Muhammadiyah Yogyakarta. Kes Mas: Jurnal Fakultas Kesehatan Masyarakat 6 (1):49-59. https://oi.org/10.12928/kesmas. v6i1.1017.

Sugiyono S (2014) Metode Penelitian Kuantitatif, Kualitatif, dan R\&D. Bandung: Alfabeta.

Sukresno H, Hakim A, Wike W, \& Afandhi A (2019) Evaluation of solid waste management regulation in Minulyo Traditional Market, Pacitan Regency, Indonesia. International Journal of Civil Engineering and Technology 10 (5):806-814.

Sulistiyorini NR, Darwis RS, \& Gutama AS (2015) Partisipasi masyarakat dalam pengelolaan sampah di lingkungan Margaluyu Kelurahan Cicurug. Share: Social Work Journal 5 (1):7180. https://doi.org/10.24198/share.v5i1.13120.

Suprapto (2005) Dampak masalah sampah terhadap kesehatan masyarakat. Jurnal Mutiara Kesehatan Indonesia 1 (2):1-4.

Syofiadi D (2019) 443.964 ton sampah tidak terkelola, DLH Sumbar: Masyarakat juga harus berperan serta menanggulangi. Covesia, 31 October. [Accessed 8 January 2020]. https://covesia.com/ archipelago/baca/85703/443-964-ton-sampah-tidak-terkelola-dlh-sumbar--masyarakatjuga-harus-berperan-serta-menanggulangi. 
Tahar N (2018) From Waste Management to Circular Economyin Indonesian Context. Jakarta: Holland Circular Hotspot.

Udawatta N, Zuo J, Chiveralls K, Yuan H, George Z, \& Elmualim A (2018) Major factors impeding the implementation of waste management in Australian construction projects. Journal of Green Building 13 (3):101-121. https://doi.org/10.3992/1943-4618.13.3.101.

Whiting K (2019) Indonesia has a plan to deal with its plastic waste problem. World Economic Forum, 13 March. [Accessed 10 January 2020]. https://www.weforum.org/agenda/2019/03/ indonesia-has-a-plan-to-deal-with-its-plastic-waste-problem.

Widyarsana IMW \& Zafira AD (2015) Kajian pengembangan sistem pengelolaan sampah di Kabupaten Tangerang. Jurnal Teknik Lingkungan 21 (1):87-97. https://doi.org/10.5614/ jt1.2015.21.1.10.

Yudhistirani SA, Syaufina L, \& Mulatsih S (2015) Desain sistem pengelolaan sampah melalui pemilahan sampah organik dan anorganik berdasarkan persepsi ibu-ibu rumah tangga. Jurnal Konversi 4 (2):29-42. https://doi.org/10.24853/konversi.4.2.29-42.

Zed M (2004) Metode Penelitian Kepustakaan. Jakarta: Yayasan Pustaka Obor Indonesia. 